\title{
PECULIARITIES OF APPLYING BALLISTIC GEL AS A SIMULATOR OF HUMAN BIOLOGICAL TISSUES
}

\author{
Filipchuk O. V., Gurov O. M.
}

The study of a mechanism of gunshot wound formation is the main task of wound ballistics. The damaging effect of the wounding projectile (the regularities in the formation of a temporary pulsating cavity) can be studied the most effectively as part of an experiment on simulators whose physical properties (density, elasticity, the capacity to absorb energy) resemble the tissues of a living human. The article presents modern capacities of applying ballistic gel as the most representative biological simulator of a living human's tissues. The article suggests priority methods of making blocks of gel, the conditions of conducting the experiment and mathematic processing of data from the perspective wounding ballistics. Due to the elastic properties of gel, the temporary pulsating cavity that emerges in the course of the wounding projectile in the same way as the living tissues collapse with the permanent wound tract. In order to evaluate the volume of the damaging effect of the wounding projectile there are used standard calculation methods: the fissure surface area (FSA), wound profile method (WPM), the total crack length method (TCL).

Keywords: gunshot injury, wound ballistic, ballistic gelatin (gel), human tissue simulator, temporary pulsating cavity.

УДК 340.6:616.711.1-001-005-079 В О. Ольховський, завідувач кафедри судової медицини, медичного правознавства Харківського національного медичного університету, доктор медичних наук, професор,

М. В. Губін, доцент кафедри судової медицини, медичного правознавства Харківського національного медичного університету, кандидат медичних наук, доцент,

O. М. Пешенко, асистент кафедри судової медицини, медичного правознавства Харківського національного медичного університету

\section{СУДОВО-МЕДИЧНА ОЦІНКА ТРАВМ ШИЙНОГО ВІДДІЛУ ХРЕБТА З УРАХУВАННЯМ ЗМІН ЦЕНТРАЛЬНОЇ ГЕМОДИНАМІКИ}

Досліджено стан иентральної гемодинаміки в постраждалих із травмами шийного відділу хребта. За результатами порівняльного аналізу доведено, щио судово-медична оцінка травм шийного відділу хребта має враховувати допплерографічні показники, серед яких найбільш інформативними є функиіональні зміни загальної мозкової й хребцевої артерій.

(c) Ольховський В. О., Губін М. В., Пешенко О. М., 2015 
Ступінь виразності ичих порушень визначається насамперед давністю та тяжкістю тілесних ушкоджень.

Ключові слова: судово-медична оцінка, тілесні ушкодження, шийний відділ хребта, изеребральна гемодинаміка, ультразвукове дослідження.

Постраждалі із травмами шийного відділу хребта (ШВХ) нерідко стають об'єктом судово-медичної експертизи живих осіб у ході судового та досудового слідств ${ }^{1}$. При цьому такі травми не завжди супроводжуються виникненням чітких морфо-клінічних проявів, що візуалізуються сучасними методами променевої діагностики. Нерідко такі ушкодження виникають у поєднанні $з$ травмами інших ділянок тіла. У цих випадках клінічна симптоматика, що зумовлена травмою ШВХ, відступає на другий план ${ }^{2}$. Це, у свою чергу, призводить до недооцінювання ступеня тяжкості тілесних ушкоджень у постраждалих з травмами ШВХ судово-медичними експертами, особливо з невеликим досвідом роботи. Разом із тим за даними сучасної спеціалізованої літератури при травмах ШВХ важливе значення мають порушення регуляції судинного тонусу центрального генезу. У більшості випадків виникають динамічні (у часі) та поширені первинні або вторинні зміни церебральної гемодинаміки й нейрорегуляторні реакції. Визначення судинних розладів у вертебробазілярному басейні, як при прямому ушкодженні, так і внаслідок рефлекторних реакцій, можливе завдяки ультразвуковій допплерографії судин шиї, зокрема, хребтових артерій. Останнім часом $\epsilon$ практично обов'язковим проведення такого дослідження всім постраждалим із неускладненою травмою ШВХ ${ }^{3}$. Високоінформативним дослідженням $\epsilon$ допплерографія хребтових артерій у функціональних положеннях: згинанні, розгинанні та ротації в бік. При цьому реєструється наявність або відсутність екстравазальної дії на хребцеві артерії, що є важливим диференціально-діагностичним критерієм в оцінюванні тяжкості травми ${ }^{4}$.

Отже, ураховуючи зазначене, метою роботи є встановлення критеріальної значущості змін функціональних розладів кровотоку екстра- та інтракраніальними судинами серед осіб із різною тяжкістю й давністю травм ШВХ.

Для дослідження залучено 107 осіб, уключаючи 64 особи з тяжкою травмою ШВХ, із вираженими морфо-клінічними проявами (ВКП) і 43 особи 3 помірними клінічними проявами (ПКП). Дослідження виконані на етапах судово-медичного клінічного моніторингу (КМ) у термін до 14 діб після отримання тілесних ушкоджень (I етап), на 22 добу (II етап). Проведено ультразвукове дослідження загальної сонної артерії (ЗСА), внутрішньої сонної артеpiї (ВСА), середніх мозкових артерій (СМА), передніх мозкових артерій (ПМА), задніх мозкових артерій (ЗМА), хребтових артерій (ХА). Досліджен-

1 Див.: Авдеев М. И. Судебно-медицинская экспертиза живых лиц / М. И. Авдеев. - М. : Медицина, 1968. - 376 с.

2 Див.: Андрейкин А. Б. О механизме образования повреждений позвоночника / А. Б. Андрейкин // Суд.-мед. эксперт. - 1989. — № 2. - С. 12-13.

3 Див.: Белова А. Н. Нейрореабилитация: руководство для врачей / А. Н. Белова. - М. : Антидор, 2000. - 568 с.

4 Див.: Ардашев И. П. Повреждение позвоночника при падении с высоты / И.П. Ардашев // Хирургия. — 1990. — № 9. — С. 41-44. 
ня особливостей мозкового кровотоку виконано із застосуванням екстра- та інтракраніальної допплерографії. Обстеження пацієнтів виконано в горизонтальному положенні - лежачи на спині. При отриманні стійких ультразвукових сигналів від судин, реєстрували графічне зображення показників кровотоку та фіксували його у вигляді допплерограм, які оцінювали якісно і кількісно за низкою загальноприйнятих показників. Зокрема, сучасними загальновизнаними індикаторами для оцінювання, крім швидкості кровотоку, вважаються: індекс опору за Pourcelot $\left(R_{i}\right)$, систолічно-діастолічний коефіцієнт $(S / D)$ і для артерій Велізієвого кола - індекс пульсації $\left(P_{i}\right)$, що розраховується за методикою Gosling. При цьому індекс $R_{i} \epsilon$ співвідношенням між максимальною систолічною та діастолічною швидкостями кровотоку, що відображає опір кровотоку дистальніше місця вимірювання. Індекс $P_{i}-$ співвідношення між різницею максимальних систолічної й діастолічної швидкостей кровотоку та середньою його швидкістю - характеризує пружно-еластичні властивості судин.

Загальна сонна артерія (ЗСА). На І етапі КМ у пацієнтів із ВКП виявлено достовірні відмінності за показниками лінійної швидкості кровотоку (достовірне за $V_{\min }$ ), зокрема ії відносне зменшення порівняно з групою пацієнтів із ПКП (табл. 1, 2).

Та бли ц я 1

Показники мозкового кровообігу при травмах ШВХ із ВКП

\begin{tabular}{|c|c|c|c|c|c|c|}
\hline \multirow{2}{*}{\multicolumn{2}{|c|}{$\begin{array}{l}\text { Судини та } \\
\text { етапи КМ }\end{array}$}} & $V_{\max }$ & $V_{\min }$ & $\boldsymbol{R}_{i}$ & $P_{i}$ & $I_{S D}$ \\
\hline & & $M \pm m, \mathbf{M} / \mathbf{c}$ & $M \pm m, \mathbf{M} / \mathbf{c}$ & $M \pm m$, од & $M \pm m$, од & $M \pm m$, од \\
\hline \multicolumn{2}{|c|}{1} & 2 & 3 & 4 & 5 & 6 \\
\hline \multirow{4}{*}{ 3CA } & $\mathrm{D}_{\mathrm{I}}$ & $0,73 \pm 0,03$ & $0,13 \pm 0,01^{\mathrm{a}, ~} 6$ & $0,82 \pm 0,01$ & $2,52 \pm 0,08$ & $5,61 \pm 0,38$ \\
\hline & $\mathrm{D}_{\mathrm{II}}$ & $0,84 \pm 0,01$ & $0,18 \pm 0,01$ & $0,78 \pm 0,01$ & $2,83 \pm 0,22$ & $4,99 \pm 0,31$ \\
\hline & $\mathrm{S}_{\mathrm{I}}$ & $0,70 \pm 0,02^{\mathrm{a}}$ & $0,13 \pm 0,01$ & $0,81 \pm 0,01^{\mathrm{a}}$ & $2,37 \pm 0,10$ & $5,38 \pm 0,36$ \\
\hline & $\mathrm{S}_{\mathrm{II}}$ & $0,82 \pm 0,01$ & $0,17 \pm 0,01$ & $0,73 \pm 0,04$ & $2,66 \pm 0,30$ & $4,29 \pm 0,44$ \\
\hline \multirow{4}{*}{ BCA } & $\mathrm{D}_{\mathrm{I}}$ & $0,68 \pm 0,02^{\mathrm{a}}$ & $0,25 \pm 0,01$ & $0,64 \pm 0,01$ & $1,70 \pm 0,07$ & $2,79 \pm 0,08$ \\
\hline & $\mathrm{D}_{\mathrm{II}}$ & $0,82 \pm 0,01^{\mathrm{a}}$ & $0,34 \pm 0,01^{\mathrm{a}}$ & $0,63 \pm 0,01$ & $1,63 \pm 0,08$ & $2,78 \pm 0,13$ \\
\hline & $\mathrm{S}_{\mathrm{I}}$ & $0,66 \pm 0,02^{\mathrm{a}}$ & $0,23 \pm 0,01^{\mathrm{a}}$ & $0,68 \pm 0,01$ & $1,75 \pm 0,06$ & $2,92 \pm 0,10$ \\
\hline & $\mathrm{S}_{\mathrm{II}}$ & $0,80 \pm 0,02$ & $0,34 \pm 0,01$ & $0,67 \pm 0,02$ & $1,75 \pm 0,08$ & $2,90 \pm 0,16$ \\
\hline \multirow{4}{*}{ CMA } & $\mathrm{D}_{\mathrm{I}}$ & $1,21 \pm 0,03$ & $0,48 \pm 0,01$ & $0,63 \pm 0,01^{\mathrm{a}}$ & $1,16 \pm 0,03$ & $2,74 \pm 0,07^{\mathrm{a}}$ \\
\hline & $\mathrm{D}_{\mathrm{II}}$ & $0,95 \pm 0,04$ & $0,51 \pm 0,01$ & $0,52 \pm 0,01$ & $1,15 \pm 0,07$ & $2,12 \pm 0,06$ \\
\hline & $\mathrm{S}_{\mathrm{I}}$ & $1,19 \pm 0,03$ & $0,47 \pm 0,03$ & $0,62 \pm 0,01^{\mathrm{a}}$ & $1,11 \pm 0,02$ & $2,65 \pm 0,05^{\mathrm{a}}$ \\
\hline & $\mathrm{S}_{\mathrm{II}}$ & $0,93 \pm 0,03$ & $0,52 \pm 0,02$ & $0,51 \pm 0,01$ & $1,14 \pm 0,06$ & $2,05 \pm 0,06$ \\
\hline
\end{tabular}


Закінчення табл. 1

\begin{tabular}{|c|c|c|c|c|c|c|}
\hline \multicolumn{2}{|c|}{1} & $\mathbf{3}$ & $\mathbf{3}$ & $\mathbf{4}$ & $\mathbf{5}$ & $\mathbf{6}$ \\
\hline \multirow{4}{*}{ ПMA } & $\mathrm{D}_{\text {I }}$ & $0,99 \pm 0,02$ & $0,43 \pm 0,01$ & $0,57 \pm 0,01$ & $0,95 \pm 0,03$ & $2,35 \pm 0,05$ \\
\cline { 2 - 7 } & $\mathrm{D}_{\text {II }}$ & $0,86 \pm 0,04$ & $0,36 \pm 0,03$ & $0,53 \pm 0,01$ & $0,85 \pm 0,03$ & $2,11 \pm 0,05$ \\
\cline { 2 - 7 } & $\mathrm{S}_{\text {I }}$ & $0,95 \pm 0,03$ & $0,43 \pm 0,01$ & $0,55 \pm 0,01$ & $0,91 \pm 0,03$ & $2,23 \pm 0,05$ \\
\cline { 2 - 7 } & $\mathrm{S}_{\text {II }}$ & $0,77 \pm 0,04$ & $0,37 \pm 0,03$ & $0,54 \pm 0,01$ & $0,85 \pm 0,03$ & $2,10 \pm 0,04$ \\
\hline \multirow{4}{*}{$3 \mathrm{MA}$} & $\mathrm{D}_{\text {I }}$ & $0,73 \pm 0,02$ & $0,31 \pm 0,01$ & $0,58 \pm 0,01^{\mathrm{a}}$ & $0,98 \pm 0,03^{\mathrm{a}}$ & $2,45 \pm 0,06^{\mathrm{a}}$ \\
\cline { 2 - 7 } & $\mathrm{D}_{\text {II }}$ & $0,54 \pm 0,01$ & $0,30 \pm 0,01$ & $0,45 \pm 0,02$ & $0,67 \pm 0,03$ & $1,86 \pm 0,06$ \\
\cline { 2 - 7 } & $\mathrm{S}_{\text {I }}$ & $0,74 \pm 0,02$ & $0,32 \pm 0,01$ & $0,57 \pm 0,01^{\mathrm{a}}$ & $0,93 \pm 0,02$ & $2,33 \pm 0,05$ \\
\cline { 2 - 7 } & $\mathrm{S}_{\text {II }}$ & $0,53 \pm 0,01$ & $0,30 \pm 0,01$ & $0,44 \pm 0,02$ & $0,64 \pm 0,04$ & $1,81 \pm 0,06$ \\
\hline \multirow{4}{*}{ XA } & $\mathrm{D}_{\text {I }}$ & $0,61 \pm 0,03^{\mathrm{a}}$ & $0,25 \pm 0,02^{\mathrm{a}}$ & $0,63 \pm 0,02^{\mathrm{a}}$ & $1,36 \pm 0,09$ & $3,19 \pm 0,22^{\mathrm{a}}$ \\
\cline { 2 - 7 } & $\mathrm{D}_{\text {II }}$ & $0,41 \pm 0,02$ & $0,19 \pm 0,01$ & $0,55 \pm 0,02$ & $1,33 \pm 0,14$ & $2,25 \pm 0,17$ \\
\cline { 2 - 7 } & $\mathrm{S}_{\text {I }}$ & $0,54 \pm 0,02^{\mathrm{a}}$ & $0,22 \pm 0,01^{\mathrm{a}}$ & $0,61 \pm 0,02^{\mathrm{a}}$ & $1,29 \pm 0,07$ & $2,97 \pm 0,19^{\mathrm{a}}$ \\
\cline { 2 - 8 } & $\mathrm{S}_{\text {II }}$ & $0,38 \pm 0,02$ & $0,17 \pm 0,01$ & $0,54 \pm 0,02$ & $1,23 \pm 0,12$ & $2,25 \pm 0,17$ \\
\hline
\end{tabular}

Примітка: $\mathrm{a}$ - достовірна різниця (при $\mathrm{p} \leq 0,05)$ між відповідними показниками на етапах КМ; б - достовірна різниця (при $\mathrm{p} \leq 0,05)$ між відповідними показниками в пацієнтів із ПКП і ВКП

Та блиц я 2

Показники мозкового кровообігу при травмах ШВХ із ПКП

\begin{tabular}{|c|c|c|c|c|c|c|}
\hline \multirow{2}{*}{\multicolumn{2}{|c|}{$\begin{array}{l}\text { Судини та } \\
\text { етапи КМ }\end{array}$}} & $V_{\max }$ & $V_{\min }$ & $\boldsymbol{R}_{i}$ & $P_{i}$ & $I_{S D}$ \\
\hline & & $M \pm m, \mathbf{M} / \mathbf{c}$ & $M \pm m, \mathbf{M} / \mathbf{c}$ & $M \pm m$, од & $M \pm m$, од & $M \pm m$, од \\
\hline \multicolumn{2}{|c|}{1} & 2 & 3 & 4 & 5 & 6 \\
\hline \multirow{4}{*}{$3 \mathrm{CA}$} & $\mathrm{D}_{\mathrm{I}}$ & $0,78 \pm 0,03$ & $0,17 \pm 0,01^{\sigma}$ & $0,81 \pm 0,01$ & $2,61 \pm 0,09$ & $5,05 \pm 0,26$ \\
\hline & $\mathrm{D}_{\text {II }}$ & $0,82 \pm 0,02$ & $0,19 \pm 0,01$ & $0,79 \pm 0,01$ & $2,81 \pm 0,11$ & $4,87 \pm 0,23$ \\
\hline & $\mathrm{S}_{\mathrm{I}}$ & $0,74 \pm 0,01^{\mathrm{a}}$ & $0,15 \pm 0,01$ & $0,80 \pm 0,01$ & $2,44 \pm 0,09$ & $5,06 \pm 0,31$ \\
\hline & $\mathrm{S}_{\mathrm{II}}$ & $0,81 \pm 0,02$ & $0,18 \pm 0,01$ & $0,74 \pm 0,06$ & $2,66 \pm 0,25$ & $4,31 \pm 0,59$ \\
\hline \multirow{4}{*}{$\mathrm{BCA}$} & $\mathrm{D}_{\mathrm{I}}$ & $0,74 \pm 0,03$ & $0,26 \pm 0,01$ & $0,63 \pm 0,01$ & $1,69 \pm 0,05$ & $2,81 \pm 0,07$ \\
\hline & $\mathrm{D}_{\mathrm{II}}$ & $0,79 \pm 0,01$ & $0,29 \pm 0,01$ & $0,61 \pm 0,01$ & $1,66 \pm 0,07$ & $2,74 \pm 0,11$ \\
\hline & $\mathrm{S}_{\mathrm{I}}$ & $0,71 \pm 0,02^{\mathrm{a}}$ & $0,27 \pm 0,01^{\mathrm{a}}$ & $0,67 \pm 0,01$ & $1,76 \pm 0,03$ & $2,87 \pm 0,12$ \\
\hline & $\mathrm{S}_{\mathrm{II}}$ & $0,81 \pm 0,02$ & $0,33 \pm 0,01$ & $0,66 \pm 0,02$ & $1,74 \pm 0,05$ & $2,79 \pm 0,14$ \\
\hline
\end{tabular}


3 акінчення табл. 2

\begin{tabular}{|c|c|c|c|c|c|c|}
\hline \multicolumn{2}{|c|}{1} & 2 & 3 & 4 & 5 & 6 \\
\hline \multirow{4}{*}{ CMA } & $\mathrm{D}_{\mathrm{I}}$ & $1,16 \pm 0,02$ & $0,49 \pm 0,01$ & $0,58 \pm 0,02^{a}$ & $1,13 \pm 0,04$ & $2,43 \pm 0,11^{\mathrm{a}}$ \\
\hline & $\mathrm{D}_{\mathrm{II}}$ & $0,97 \pm 0,03$ & $0,52 \pm 0,02$ & $0,53 \pm 0,02$ & $1,11 \pm 0,06$ & $2,18 \pm 0,09$ \\
\hline & $\mathrm{S}_{\mathrm{I}}$ & $1,13 \pm 0,04$ & $0,48 \pm 0,04$ & $0,58 \pm 0,02^{\mathrm{a}}$ & $1,12 \pm 0,03$ & $2,41 \pm 0,08^{\mathrm{a}}$ \\
\hline & $\mathrm{S}_{\mathrm{II}}$ & $0,95 \pm 0,02$ & $0,51 \pm 0,03$ & $0,49 \pm 0,03$ & $1,13 \pm 0,05$ & $2,12 \pm 0,05$ \\
\hline \multirow{4}{*}{ ПМА } & $\mathrm{D}_{\mathrm{I}}$ & $0,95 \pm 0,04^{\mathrm{a}}$ & $0,40 \pm 0,02$ & $0,55 \pm 0,01$ & $0,93 \pm 0,02^{\mathrm{a}}$ & $2,28 \pm 0,08^{a}$ \\
\hline & $\mathrm{D}_{\mathrm{II}}$ & $0,87 \pm 0,03$ & $0,38 \pm 0,02$ & $0,54 \pm 0,01$ & $0,87 \pm 0,02$ & $2,13 \pm 0,04$ \\
\hline & $\mathrm{S}_{\mathrm{I}}$ & $0,91 \pm 0,04^{\mathrm{a}}$ & $0,41 \pm 0,01$ & $0,54 \pm 0,01$ & $0,89 \pm 0,03^{\mathrm{a}}$ & $2,19 \pm 0,03$ \\
\hline & $\mathrm{S}_{\mathrm{II}}$ & $0,79 \pm 0,05$ & $0,39 \pm 0,02$ & $0,53 \pm 0,01$ & $0,83 \pm 0,02$ & $2,13 \pm 0,03$ \\
\hline \multirow{4}{*}{ 3MA } & $\mathrm{D}_{\mathrm{I}}$ & $0,66 \pm 0,04^{\mathrm{a}}$ & $0,32 \pm 0,01$ & $0,52 \pm 0,01$ & $0,84 \pm 0,05^{\mathrm{a}}$ & $2,29 \pm 0,04^{\mathrm{a}}$ \\
\hline & $\mathrm{D}_{\mathrm{II}}$ & $0,57 \pm 0,02$ & $0,31 \pm 0,01$ & $0,48 \pm 0,03$ & $0,70 \pm 0,02$ & $1,91 \pm 0,02$ \\
\hline & $\mathrm{S}_{\mathrm{I}}$ & $0,69 \pm 0,04^{\mathrm{a}}$ & $0,32 \pm 0,02$ & $0,53 \pm 0,02$ & $0,90 \pm 0,07^{a}$ & $2,21 \pm 0,09^{\mathrm{a}}$ \\
\hline & $\mathrm{S}_{\mathrm{II}}$ & $0,52 \pm 0,03$ & $0,30 \pm 0,02$ & $0,48 \pm 0,04$ & $0,67 \pm 0,05$ & $1,82 \pm 0,05$ \\
\hline \multirow{4}{*}{$\mathrm{XA}$} & $\mathrm{D}_{\mathrm{I}}$ & $0,55 \pm 0,02^{\mathrm{a}}$ & $0,23 \pm 0,02$ & $0,60 \pm 0,03$ & $1,33 \pm 0,06$ & $2,68 \pm 0,19^{a}$ \\
\hline & $\mathrm{D}_{\mathrm{II}}$ & $0,44 \pm 0,06$ & $0,20 \pm 0,02$ & $0,56 \pm 0,04$ & $1,31 \pm 0,11$ & $2,28 \pm 0,13$ \\
\hline & $\mathrm{S}_{\mathrm{I}}$ & $0,48 \pm 0,04^{\mathrm{a}}$ & $0,22 \pm 0,02$ & $0,60 \pm 0,04^{\mathrm{a}}$ & $1,26 \pm 0,05$ & $2,71 \pm 0,16^{\mathrm{a}}$ \\
\hline & $\mathrm{S}_{\mathrm{II}}$ & $0,39 \pm 0,03$ & $0,18 \pm 0,02$ & $0,53 \pm 0,03$ & $1,24 \pm 0,09$ & $2,27 \pm 0,12$ \\
\hline
\end{tabular}

Примітка: а - достовірна різниця (при $\mathrm{p} \leq 0,05$ ) між відповідними показниками на етапах моніторингу

При цьому мав місце більший циркуляторний опір $\left(R_{i}\right)$ за умов відсутності асиметрії кровотоку $\left(\mathrm{D}_{\mathrm{I}}=\mathrm{S}_{\mathrm{I}}\right)$, збереження індексу пульсації $\left(P_{i}\right)$ і систоло-діастолічного коефіцієнта $\left(I_{S D}\right)$. Це свідчить про наявність безпосередньо після травми в пацієнтів із ВКП відносно більш високого периферичного опору в басейні кровопостачання 3СА та може бути пояснено впливом кількох факторів: підвищеною в’язкістю крові, підвищенням внутрішньочерепного тиску, зростанням тонусу капілярів.

Внутрішня сонна артерія (ВСА). На І етапі КМ у пацієнтів із ВКП виявлено відмінності за показниками лінійної швидкості кровотоку (за $V_{\max }$ ), зокрема її відносне зменшення порівняно з групою пацієнтів із ПКП. Це свідчить про наявність безпосередньо після тілесних ушкоджень судинногемодинамічної реакції у вигляді зменшення максимальної лінійної швидкості кровотоку, що може бути пояснено максимальним підвищенням тонусу ВСА. 
На II етапі КМ відмінності у швидкості кровотоку по ВСА між особами порівнюваних груп характеризувались більшим зростанням при травмах із ВКП як $V_{\max }$, так і $V_{\text {min }}$, що демонструє компенсаторний характер реакції ВСА.

Передня мозкова артерія (ПМА). На І етапі КМ у пацієнтів із ВКП за показниками лінійної швидкості кровотоку значущих відмінностей не виявлено. На II етапі КМ зареєстровано зменшення швидкості кровотоку, як при травмах із ВКП, так і при травмах із ПКП, що є фізіологічним.

Задня мозкова артерія (ЗМА). На І етапі КМ у пацієнтів із ВКП на тлі стабільних показників лінійної швидкості кровотоку значущих відмінностей не виявлено. При цьому мало зростання (порівняно з ПКП) індексу $R_{i}$ та коефіці$\epsilon$ нта $I_{S D}$. Це свідчить про наявність безпосередньо після травми в пацієнтів із ВКП судинно-гемодинамічної реакції у вигляді зменшення амплітуди. На II етапі КМ відмінності в показниках швидкості кровотоку по ЗМА між пацієнтами 3 порівнюваних груп характеризувались достовірно більш виразним зменшенням у постраждалих із ВКП периферичного опору судин і коефіцієнта $I_{S D}$.

Хребиева артерія (XА). На І етапі КМ у пацієнтів із ВКП зростали показники лінійної швидкості кровотоку (порівняно з ПКП), індекс $R_{i}$ та коефіцієнт $I_{S D}$. Це свідчить про наявність безпосередньо після травми в пацієнтів із ВКП судинно-гемодинамічної реакції зі зростанням циркуляторного опору судин. На II етапі КМ відмінності в показниках швидкості кровотоку по ХА між пацієнтами з ВКП і ПКП не виявлено. Наведене свідчить про клінічну інформативність порушень кровотоку по ХА, що можна розглядати як несприятливий індикатор формування ускладненого перебігу травми.

Узагальнений аналіз патернів судинно-рефлекторних реакцій і їх допплерографічних індикаторів на етапах моніторингу свідчить про більш виражене порушення регуляторних механізмів центрального генезу в осіб із ВКП травми. Зокрема, на I етапі КМ у пацієнтів із ВКП травми, на відміну від пацієнтів із ПКП травми, виявлено зростання циркуляторного опору в басейні кровопостачання СМА, ЗМА, ХА при одночасному зменшенні максимальної швидкості кровотоку в ЗСА, ВСА та їі зростання в ХА, що, по-перше, демонструє дисоціативний характер кровозабезпечення, а по-друге, призводить до порушення кровонаповнення мозку. При цьому зростання мінімальної швидкості кровотоку у ВСА й ХА (при ії зменшенні в ЗСА) впливає на зростання систоло-діастолічного коефіцієнта в ЗМА та ХА, що має компенсаторний характер. Отже, на І етапі КМ у осіб із ВКП травми, на відміну від осіб із ПКП травми, має місце функціональна неузгодженість судинних реакцій, що можна трактувати як порушення центральних механізмів регуляції судинного тонусу.

На ІІ етапі КМ в осіб із ВКП виявлено зменшення циркуляторного опору в басейні СМА та ПМА, тоді як у басейнах ЗМА й ХА він залишався високим або й надалі зростав. Це відбувалося за рахунок зменшення швидкості кровотоку в басейні СМА при збереженні максимальних показників кровотоку в басейні ХА. Незважаючи на це, індекс пульсації в ПМА, ЗМА знижувався. Слід зазначити, що зниження у пацієнтів із ПКП травми систоло-діастолічного коефіцієнта та зростання циркуляторного опору в басейні CMA, а також мінімальної і максимальної швидкостей кровотоку в басейні 
ЗСА лише підтверджує загальні прояви порушень механізму регуляції судинного тонусу, що в цій групі має менш виразний та безсистемний характер.

Порівняльний клініко-інформаційний аналіз функціональних розладів кровотоку виявив, що судинно-рефлекторні реакції в осіб із травмами ШВХ мають диференційно-діагностичне й прогностичне значення. 3'ясовано, що найбільш інформативними для прогнозування пребігу травми є рефлекторні реакції ЗСА, ВСА та ХА. 3 клінічної точки зору це пояснюється спільністю нейрорефлекторних і гемодинамічних реакцій судин головного мозку та шийного відділу хребта, що й визначає особливості кровозабезпечення паравертебральних тканин безпосередньо в місці ушкодження та зоні травми. При судово-медичній оцінці травм ШВХ, об'єктивні показники зазначених змін гемодинаміки дозволять провести диференційну діагностику між застарілими ушкодженнями й гострою травмою, об’єктивізувати визначення тривалості розладу здоров'я в постраждалих.

Отже, проведені дослідження дозволили зробити певні висновки.

1. При різних за ступенем тяжкості травмах ШВХ виявлені відмінні допплерографічні показники, серед яких найбільш інформативними є функціональні зміни загальної мозкової та хребцевої артерій.

2. Аналіз функціональних розладів кровотоку виявив, що судинно-рефлекторні реакції в постраждалих з ушкодженнями ШВХ мають диференційнодіагностичне й прогностично-експертне значення та можуть бути використані як додаткові критерії при визначенні ступеня тяжкості тілесних ушкоджень.

3. 3'ясовано, що найбільш інформативними для оцінювання ступеня тяжкості тілесних ушкоджень є гемодинамічний стан загальної сонної, внутрішньої сонної й хребцевої артерій.

4. Доведено необхідність застосування методів неінвазійної діагностики судинних реакцій (гемодинамічних змін), що виникають унаслідок травм ШВХ, які дозволять з необхідною точністю та достовірністю визначати ступінь тяжкості тілесних ушкоджень.

\title{
СУДЕБНО-МЕДИЦИНСКАЯ ОЦЕНКА ТРАВМ ШЕЙНОГО ОТДЕЛА ПОЗВОНОЧНИКА С УЧЕТОМ ИЗМЕНЕНИЙ ЦЕНТРАЛЬНОЙ ГЕМОДИНАМИКИ
}

\author{
Ольховский В. А., Губин Н. В., Пешенко А. Н.
}

Исследовано состояние иентральной гемодинамики у пострадавших с травмами шейного отдела позвоночника. По результатам сравнительного анализа доказано, что судебно-медииинская оиенка травм шейного отдела позвоночника должна учитывать допплерографические показатели, среди которых наиболее информативными являются функииональные изменения общей мозговой и позвоночной артерий. Степень выразительности этих нарушений определяется прежде всего давностью и тяжестью телесных повреждений.

Ключевые слова: судебно-медицинская оценка, телесные повреждения, шейный отдел позвоночника, церебральная гемодинамика, ультразвуковое исследование. 


\title{
FORENSIC MEDICAL ASSESSMENT \\ OF CERVICAL SPINE TRAUMAS WITH THE ACCOUNT OF CHANGES IN CENTRAL HEMODYNAMICS
}

\author{
Olkhovskiy V. A., Gubin N. V., Peshenko A. N.
}

The article analyzes the up-to-date state and problematic issues of forensic medical diagnosis of cervical spine injuries. It establishes that there are cases when forensic medical experts underestimate the outcomes and consequences of this trauma. It studies the state of the central hemodynamics of the injured with cervical spine traumas. At the same time 107 injured were divided into two groups: with clear and moderate manifestations. The research applied an objective and modern method of Doppler echocardiography. The conducted research has demonstrated significant changes in extra- and intracerebral blood flow. The results of the comparative analysis show that forensic medical assessment of cervical spine traumas should take into account the results of Doppler echocardiography. Among these results the most informative are functional changes of the cerebral and spinal arteries. The manifestation of these deviations is determined, primarily, by the severity and time of injuries. The article determines the ways of improving forensic medical examinations of the injured with cervical spine traumas. It demonstrates the criteria significance of changes in bloodflow of cerebral and cervical arteries of the injured while establishing the severity of injuries.

Keywords: forensic medical assessment, bodily injuries y, cervical spine, cerebral hemodynamics, ultrasound study.

УДК 340.624 .3

I. М. Козаченко, доцент кафедри судовомедичної експертизи Харківської медичної академії післядипломної освіти, кандидат медичних наук, доцент

\section{ВИЗНАЧЕННЯ ВИДУ ПНЕВМАТИЧНОЇ ЗБРОЇ ЗА ДЕЯКИМИ МОРФОЛОГІЧНИМИ ОСОБЛИВОСТЯМИ ВХІДНИХ КУЛЬОВИХ ПОШКОДЖЕНЬ НА ЩІЛЬНИХ ПЕРЕШКОДАХ}

Виконано експериментальні постріли по листам картону із двох пневматичних гвинтівок калібру 4,5 мм із 6-ма й 12-ма правопохилими нарізами каналу ствола кулями шести марок із різною формою головної частини. У результаті пострілів зі зброї з 6-ма нарізами пошкодження мають вигляд правильного шестикутника. Для зброї з 12-ма нарізами характерна форма пошкоджень у вигляді шестерні з відбитками полів нарізів ствола в пояску обтирання кулі. Уперше доведено можливість за морфологічними особливостями кульових пошкоджень на щільних перешкодах визначити кількість нарізів ствола пневматичної зброї.

Ключові слова: пневматична гвинтівка, поля нарізів, головна частина кулі, шестикутник, шестерня, поясок обтирання кулі. 